\title{
Sektor Pariwisata terhadap Pembangunan Daerah di Kabupaten Lumajang
}

\author{
M. Fathorrazi ${ }^{1}$, Hr.Cahyo Diartho ${ }^{2}$, Mi'ilya Khoijah ${ }^{3}$ \\ Jurusan IImu Ekonomi, Fakultas Ekonomi dan Bisnis, Universitas Jember ${ }^{123}$ \\ Email: hermancahyodiartho@yahoo.com
}

https://doi.org/10.30741/wiga.v9i1.367

I N F O A R T I K E L

Tanggal masuk :

20 Februari 2019

Tanggal Revisi :

15 Maret 2019

Tanggal Diterima :

31 Maret 2019

\section{A B S T R A K}

Penelitian ini merupakan penelitian Descriptive yang bertujuan untuk mengetahui seberapa besar tingkat elastisitas tenaga kerja sub sektor pariwisata di Kabupaten Lumajnag, mengetahui kontribusi sub sektor pariwisata terhadap Pendapatan Asli Daerah (PAD) di Kabupaten Lumajang, serta mengetahui pertumbuhan penyerapan tenaga kerja pada sub sektor pariwisata di Kabupaten Lumajang. Jenis data yang digunakan dalam penelitan ini adalah data sekunder yang berupa data time series dengan objek penelitian pada sub sektor pariwisata di Kabupaten Lumajang dan data diperoleh dari Dinas Pariwisata, Dinas tenagakerja dan Dinas pendapatan Kabupaten Lumajang tahun 2011-2017. Metode analisis data yang digunakan dalam penelitian ini adalah analisis elastisitas dan proporsi. Hasil penelitian ini menunjukkan bahwa kemampuan sub sektor pariwisata tidak banyak di dalam penyerapan tenaga kerja yaitu sebesar $-1,49$ persen dari jumlah tenaga kerja yang sudah bekerja atau dikategorikan sebagai inelastis artinya setiap kenaikan nilai pendapatan sektor pariwisata tidak diikuti dengan peningkatan penyerapan tenaga kerja. Selain itu sub sektor pariwisata juga tidak memberikan kontribusi yang lumayan besar selama kurun waktu 2011-2017 terhadap Pendapatan Asli Daerah Kabupaten Lumajang yaitu rata-rata hanya sebesar 1.41 persen. Keseluruhan kontribusi atau sumbangan yang diberikan sub sektor pariwisata dari tahun ke tahun selama kurun waktu 2011-2017 cenderung mengalami penurunan.

Kata Kunci : Elastisitas, Pendapatan Asli Daerah (PAD), Penyerapan Tenaga Kerja, Proporsi dan Sub sektor pariwisata

\begin{abstract}
A B S T R A C T
This research is a Descriptive research which aims to find out how much the level of labor elasticity of tourism subsector in Lumajnag regency, to know contribution of tourism subsector to local revenue (PAD) in Lumajang Regency, and to know the growth of labor absorption in tourism sector in Lumajang regency. The type of data used in this research is secondary data in the form of time series data with the object of research on the tourism subsector in Lumajang District and data obtained from the Department of Tourism, Department of Manpower and Dinas revenue Lumajang District in 2011-2017. Data analysis method used in this research is elasticity and proportion analysis. The results of this study indicate that the ability of the tourism subsector is not much in the absorption of labor that is equal to 1.49 percent of the number of workers who have worked or categorized as inelastic. In addition, the tourism subsector also did not contribute a considerable amount during the period of 2011-2017 to the Regional Original Income of Lumajang Regency which averaged only 1.41 percent.
\end{abstract}


Overall contribution or contribution given by the tourism sector from year to year during the period 2011-2017 tends to decrease.

Keywords: Elasticity, Local Original Income (PAD), Employment Absorption, Proportion and Tourism Sector

\section{PENDAHULUAN}

Pembangunan nasional merupakan suatu transformasi ekonomi, sosial dan budaya melalui kebijakan dan strategi menuju arah yang di inginkan (Adisasmita, 2013:31). Kelangsungan dalam pembangunan nasional disamping untuk meningkatkan pendapatan nasional, sekaligus juga harus menjamin pembagian pendapatan yang merata bagi seluruh lapisan masyarakat yang secara keseluruhan menuju kondisi yang lebih baik untuk meningkatkan taraf hidup maupun kesejahteraan suatu kehidupan masyarakat (Mustika, 2009). Teori pertumbuhan ekonomi menurut Adam Smith (Ahman, 2006). berkaitan dengan dua unsur pertumbuhan, yaitu pertumbuhan output total dan pertumbuhan penduduk. Pertumbuhan output dipengaruhi oleh tiga unsur pokok yaitu: 1) Sumber-sumber alam, 2) Sumber-sumber tenaga kerja (jumlah penduduk). 3) Jumlah modal.

Pembangunan nasional suatu negara dapat dilakukan dengan cara peningkatan pertumbuhan ekonominya. Kegiatan peningkatan pertumbuhan perekonomian ini terkait dengan peningkatan perekonomian daerah termasuk meningkatkan Pendapatan Asli Daerah (PAD). Salah satu upaya peningkatan PAD yakni dengan mengelola sumber daya yang ada di suatu wilayah, baik itu sumber daya alam maupun sumber daya manusia (Maulana, 2016). Dari 16 Sektor yang ada, pariwisata merupakan sub sektor dari salah satu sektor yang menarik untuk di kembangkankan guna mencapai pertumbuhan ekonomi di suatu wilayah, di sini sektor pariwisata dapat menyerap sumber daya alam dan sumber daya manusia secara bersama-sama (Utami, 2016). Sektor pariwisata menurut Sasongko (2013) merupakan salah satu sektor yang memiliki kontribusi dalam penerimaan pendapatan. Kabupaten Lumajang merupakan salah satu kota kecil yang melaksanakan otonomi daerah dengan membangun sektor pariwisata sebagai penunjang dalam meningkatkan pertumbuhan ekonomi (Setiabudi, 2016).

Pariwisata merupakan salah satu sektor yang menjadi andalan pemerintah daerah untuk menambah pendapatan daerah. Sehingga Kabupaten Lumajang berkomitmen menempatkan pariwisata sebagai sektor prioritas, komitmen ini dibuktikan pemerintah Kabupaten Lumajang yang telah menetapkan peraturan daerah (PERDA) nomor 14 tahun 2011 tentang tempat rekreasi, retribusi, dan olahraga. Bahwa dalam rangka pemanfaatan tempat rekreasi dan olahraga guna meningkatkan daya guna dan hasil guna tempat rekreasi dan olahraga untuk meningkatkan pendapatan daerah. Dan sehubungan dengan visi pemerintah daerah yang tertuang dalam RPJMD Kabupaten Lumajang tahun 2015-2019 yaitu "Terwujudnya Kabupaten Lumajang sebagai daerah tujuan wisata berbasis kearifan lokal yang berpeluang investasi serta mampu memberikan multiplier effect terhadap pertumbuhan ekonomi daerah" PERDA nomor 1 tahun 2014 pariwisata masuk kedalam lima sektor yang paling diandalkan berbagai program dikembangkan untuk menggenjot pariwisata bersama stekholder lainnya.

Sektor pariwisata teramsuk kedalam kategori jasa-jasa lainnya. Dalam beberapa tahun teakhir kabupaten Lumajang terus melakukan pengembangan sektor pariwisatanya karna sektor tersebut dinilai bisa ikut menjadi pengungkit di berbagai sektor dimasyarakat dan dapat meningkatkan pertumbuhan ekonominya dengan pengembangan objek wisata di kabupaten Lumajang. Pengembangan pariwisata dapat ditempuh melalui, pengembangan jalur wisata, pengadaan sarana dan prasarana penunjang pariwisata seperti hotel dan penginapan serta peningkatan aksesbilitas dengan meningkatkan kondisi jalan dan penyediaan sarana transportasi menuju obyek wisata. Pengembangan sektor pariwisata ini di maksudkan untuk mengurangi ketergantungan terhadap 
sektor pertanian di lihat dari dominasinya yang sampai saat ini kebanyak dari masyarakat Lumajang masih sebagian besar bergantung pada sektor pertanian (Anwar, 2014).

\section{METODE PENELITIAN}

Penelitian ini merupakan penelitian Descriptive yaitu jenis penelitian yang mampu menggambarkan kontribusi sektor pariwisata terhadap penyerapan tenaga kerja dan Pendapatan Asli Daerah di Kabupaten Lumajang. Penelitian ini merupakan penelitian deskriptif dengan paradigma penelitian kuantitatif dan kualitatif. Lokasi yang digunakan untuk penelitian ini adalah sektor pariwisata di Kabupaten Lumajang sebagai pilihan penulis, disebabkan karan banyak potensi wisata di Kabupaten Lumajang perlu digali dan dikembangkan, selain itu dengan di perolehnya Anugrah Pesona Indonesia tahun 2017 untuk wisata Air Terjun Tumpak Sewu menjadi nominasi surga yang tersembunyi. Jenis data dalam penelitian ini adalah data primer dan data sekunder yang telah dikumpulkan oleh instansi atau badan tertentu yang telah tersusun dengan baik dan siap diolah, yaitu data tersusun tahun 2011-2017 berupa data runtut waktu (time series). Data dalam penelitian ini diperoleh dari dinas pendapatan daerah, badan pusat statistik kabupaten Lumajang, dinas kebudayaan dan pariwisata Kabupaten Lumajang dan studi pustaka.

Untuk mengetahui laju pertumbuhan tenaga kerja pada sektor pariwisata digunakan model sebagai berikut, dengan rumus (Mulyadi, 1998:86).

$L^{0}=\frac{T K_{t}-T K_{t-1}}{T K_{t-1}} \times 100 \%$

Dimana :

$\mathrm{L}^{0} \quad=$ Pertumbuhan tenaga kerja sektor pariwisata

$\mathrm{TK}_{\mathrm{i}}=$ Tenaga kerja pada tahun $\mathrm{i}$

$\mathrm{TK}_{\mathrm{i}-1}=$ Tenaga kerja pada tahun $\mathrm{i}-1$

Untuk mengetahui besarnya proporsi atau kontribusi dari sektor pariwisata terhadap Pendapatan Asli Daerah, maka digunakan analisis proporsi dengan rumus (Djarwanto, 2001:152).

$\mathrm{Z}={ }^{\frac{X_{m}}{Y_{m}}} \times 100 \%$

Dimana :

$\mathrm{Z}=$ Proporsi penerimaan sektor pariwisata terhadap Pendapatan Asli Daerah

$X_{m}=$ Penerimaan sektor pariwisata

$Y_{m}=$ Pendapatan Asli Daerah

Untuk mengatahui laju pertumbuhan nilai pendapatan dari sektor pariwisata, maka dapat di gunakan rumus (Mulyadi, 2000;86).

$Q^{0}=\frac{Q_{t-Q_{t-1}}}{Q_{t-1}} \times 100 \%$

Dimana :

$\mathrm{Q}^{0}=$ Pertumbuhan nilai pendapatan sektor pariwisata

$\mathrm{Q}_{\mathrm{t}}=$ Nilai pendapatan sektor pariwisata pada tahun $\mathrm{t}$

$\mathrm{Q}_{\mathrm{t}-1}=$ Nilai pendapatan sektor pariwisata pada tahun $\mathrm{t}-1$

\section{HASIL DAN PEMBAHASAN}

Elastisitas penyerapan tenaga kerja pada sektor pariwisata pada tahun 2011-2012 adalah sebesar 1,49 persen. Hal ini dapat dikatakan bahwa sektor pariwisata di Kabupaten Lumajang memiliki penyerapan tenaga kerja yang Inelastis karena memiliki nilai $-1,49$ yang berarti kurang dari 1 sehingga temasuk didalam karakteristik inelastis, artinya apabila $\prod \mathrm{N}<1$ persentase perubahan 
pendapatan sektor pariwisata lebih besar dari persentase perubahan penyerapan tenaga kerja maka dikatakan inelastis. karena -1,49 persen kurang dari 1 maka berada dalam kategori inelastis. artinya setiap kenaikan nilai pendapatan sektor pariwisata sebesar 1 persen di ikuti dengan penyerapan tenaga kerja di sektor pariwisata kurang dari 1 persen yaitu sebesar $-1,49$ persen. Hal ini dapat dikatakan bahwa sektor pariwisata di Kabupaten Lumajang memiliki penyerapan tenaga kerja yang inelastis.

Penyerapan tenaga kerja sektor pariwisata di kabupaten Lumajang dalam kurun waktu 2011-2017 memiliki suatu spesialisasi hal ini di karenakan kabupaten Lumajang memiliki potensi budaya dan keindahan alam yang mulai berkembang disetiap daerahnya dengan potensi yang dimiliki setiap daerah sehingga hal ini dapat menjadikan kabupaten Lumajang mampu menarik dan mendatangkan para wisatawan untuk berkunjung dan berwisata di kabupaten Lumajang.Mengingat kemampuan sektor pariwisata yang tidak banyak di dalam penyerapan tenaga kerja, maka upayaupaya pengembangan sektor ini masih perlu di tingkatkan karena akan menambah kuatnya perekonomian dan kesejahteraan masyarakat umum, khususnya masyarakat sekitar dimana terdapat obyek atau tempat wisata. Sehingga nantinya sektor priwisata diharapkan akan mampu menciptakan kesempatan kerja yang luas.

Hasil penelitian yang dilakukan oleh Rizkhi (2015) di Kabupaten Banyuwangi dijelaskan bahwa objek wisata berdampak meningkatkan pendapatan daerah dan hasil penelitiannya menunjukkan bahwa kemampuan sektor pariwisata tidak banyak di dalam penyerapan tenaga kerja yaitu sebesar $1,21 \%$ dari jumlah tenaga kerja yang sudah bekerja atau di kategorikan sebagai elasti. Sedangkan hasil penelitian yang dilakuakan oleh Trisnanda (2015) yang dilakukan di kabupaten banyuwangi menunjukkan bahwa hasil dari elastisitas penyerapan tenaga kerja pada sektor pariwisata dala kurun waktu 2008-2013 bersifat inelastis. Dan hasil penelitian yang dilakukan oleh Anwar (2014) di kabupaten malang menunjukkan bahwa kemampuan sektor pariwisata tidak banyak di dalam penyerapan tenaga kerja yaitu sebesar $0,65 \%$ dari jumlah tenaga kerja yang sudah bekerja atau dikategorikan sebagai inelastis. Dari hasil penelitian yang dilakukan oleh 3 orang tersebut yang hasilnya sama dengan yang dilakuakan oleh peneliti yaitu penelitian oleh Trisnanda (2015) yang dilakukan di kabupaten Banyuwangi bersifat inelastis dan penelitian yang dilakukan oleh Anwar (2014) di kabupaten Malang juga menunjukkan hasil inelastis. Dima hasil penelitian yang peneliti lakukan hasilnya juga bersifat inelastis. Semua hasil penelitian ini sesuai karna perkembangan pariwisata dapat memberikan dampak positif adanya penyerapan tenaga kerja meskipun sedikit.

Pertumbuhan ekonomi suatu daerah dapat dilihat salah satunya pada laju pertumbuhan Pendapatan Asli daerah (PAD) yang merupakan pendapatan pemerintah daerah dari hasil pajak daerah, hasil retribusi daerah, hasil perusahaan daerah dan laba usaha daerah yang sah. Peningkatan Pendapatan Asli daerah menandakan suatu keberhasilan dari proses pembangnan. Sektor pariwisata memberikan kontribusi yang kecil selama kurun waktu 2011-2017 terhadap Pendapatan Asli Daerah Kabupaten Lumajang. Secara keseluruhan kontribusi atau sumbangan yang diberikan sektor pariwisata dari tahun ke tahun selama kurun waktu 2011-2017 cenderung mengalami penurunan.Pada tahun 2011 kontribusi sektor pariwisata terhadap Pendapatan Asli Daerah sebesar 1,93 persen dari jumlah total Pendapatan Asli Daerah. Tahun 2012 sebesar 1,75 persen, sedangkan tahun 2013 sebesar 1,82 persen. Untuk tahun 2014 sebesar 1,18 persen dan pada tahun 2015 sebesar 1,14 persen. Sedangkan kontribusi terendah terjadi pada tahun 2016 yang sebesar 1,00 persen dan yang terakhir tahun 2017 sebesar 1,03 persen dari jumlah total Pendapatan Asli Daerah Kabupaten Lumajang.

Kontribusi pendapatan sektor pariwisata terhadap Pendapatan Asli daerah dari tahun 2011-2017 mengalami fluktuasi dari tahun ke tahun ini menunjukkan bahwa sumbangan sektor pariwisata terhadap Pendapatan Asli Daerah Kabupaten Lumajang pengaruhnya naik turun dari tahun ke tahun sehingga perlu dilakukan pengembangan lebih baik lagi sehingga bisa menyumbangkan kontribusinya terhadap Pendapatan Asli Daerah lebih banyak lagi pada tahun-tahun yang akan 
datang, Pembangunan sektor pariwisata nantinya juga diharapkan mampu mengurangi kemiskinan absolute, menciptakan distribusi pendapatan yang merata dan menciptakan perangsang bagi pemerintah untuk lebih banyak mengajak para investor untuk menanamkan investasinya pada sektor pariwisata dan pada akhirnya semuanya akan mampu memberikan kontribusi terhadap Pendapatan Asli daerah dengan maksimal, sehingga dapat memperlancar dan membantu pembangunan Kabupaten Lumajang.

Hasil penelitian yang dilakukan oleh Anwar (2014) di Kabupaten Malang pada tahun 2008-2013 dijelaskan bahwa kemampuan sektor pariwisata dalam memberikan kontribusi yang cukup selama kurun waktu 5 tahun terhadap pendapatan asli daerah kabupaten Malang yaitu rata-rata hanya sebesar 3,39\%. Sedangkan hasil penelitian yang dilakukan oleh Trisnanda (2015) di kabupate Banyuwangi dijelaskan bahwa secara keseluruhan kontribusi atau sumbangan yang diberikan sektor pariwisata terhadap pendapatan asli daerah selama 2009-2013 mengalami fluktuasi dari tahun ke tahun dan cenderung memberikan kontibusi yang sedikit terhadap pendapatan asli daerah yaitu rata-rata hanya sebesar $1,45 \%$. Dari hasil penelitian ini sesuai karna perkembangan sektor pariwisatamemberikan kontribusi terhadap pendapatan asli daerah meskipun sedikit.

\section{KESIMPULAN}

Hasil penelitian terhadap sub sektor pariwisata dalam kerangka pembangunan daera dapat disimpulkan bahwa : (a). Elastisitas penyerapan tenaga kerja pada sektor pariwisata kabupaten Lumajang selama kurun waktu 2011-2017 bersifat inelastis artinya setiap kenaikan nilai pendapatan sektor pariwisata tidak diikuti dengan peningkatan penyerapan tenaga kerja, hal tersebut menunjukkan bahwa kemampuan sektor pariwisata tidak banyak di dalam penyerapan tenaga kerja dan (b). Kontribusi pendapatan objek wisata yang dikelola pemerintah daerah terhadap pendapatan asli daerah dari tahun 2011-2017 mengalami fluktuasi tiap tahunnya tetapi cenderung turun sehingga perlu dilakukan pengembangan yang lebih baik. Berdasarkan hasil perhitungan peneliti kemampuan objek wisata yang dikelola pemerintah daerah kabupaten Lumajang dalam menyumbang pendapatan asli daerah kabupaten Lumajang sangat kecil.

\section{DAFTAR PUSTAKA}

Adisasmita, R. (2013). Teori-teori pembangunan Ekonomi Pertumbuhan Ekonomi dan Pertumbuhan Wilayah. Yogyakarta: Graha Ilmu.

Ahman, E. \& Indriani, E. (2006). Membina Kompetensi Ekonomi. Jakarta: Grafindo Media Pratama.

Anwar, dkk. (2014). Peranan Sektor Pariwisata Terhadap Penyerapan Tenaga Kerja dan PAD di Kabupaten Malang. E-Journal EP : UNEJ

Maulana, A. (2016). Pengaruh Kunjungan Wisatawan Mancanegara dan Perjalanan Wisatawan Nusantara Terhadap Penyerapan Tenaga Kerja Sektor Pariwisata di Indonesia. E-Journal Vol.1 no 1 ISSN

Mustika, M. D. S. (2009). Investasi Swasta Sektor Pariwisata dan Penyerapan Tenaga Kerja di Provinsi Bali (Sebuah analisis tipologi daerah). E-Journal FES-Udayana.

Sasongko, Probo, Trijayanti, Dewie. (2013). Analisis Penyerapan Tenaga Kerja Sektor Perhotelan dan Restoran di Kecamatan Pacet Kabupaten Mojokerto. E-Journal Menejenem Vol.1 no.3

Setiabudi, A. (2016). Pembangunan Sektor Pariwisata dalam Meningkatkan Pendapatan Asli Daerah (Studi Pada Dinas Kebudayaan dan Pariwisata Kabupaten Lumajang). E-Journal Vol.4 no.3 - UB: Adminitrasi Publik

Utami, R.C dan Hartono, D. (2016). Anlisis Daya Saing Harga Pariwisata Indonesia Pendekatan Elastisitas Permintaan: Jurnal Kepariwisataan Indonesia Vol.11 No. 1.www.kemenpar.gp.id/asp/detil.asp?c=101\&id=3490 